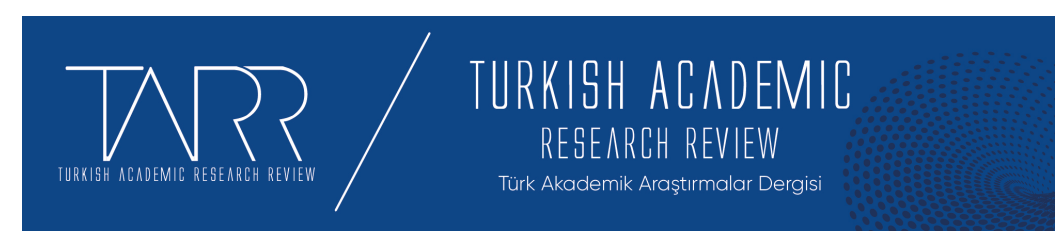

e-ISSN: 2602-2923 Yll/Year: 2021 Cilt/Volume: 6 Sayı/Issue: 3

\title{
Pîr Muhammed Mevlevî’nin Hazînetü'l-Ebrâr İsimli Eserinin 4. Cildinde Bir Ayetin İrşat Şekli
}

Guidance Form of a Verse in the 4th Volume of Pir Muhammad Mawlawi's Khazinat al-Abrar

\section{Abdullah UÇAR}

Öğretim Görevlisi, Aksaray Üniversitesi / Lecturer, Aksaray University, ucarabdullah@gmail.com, Orcid ID: 0000-0003-1391-8681

\begin{tabular}{r|l} 
Makale Bilgisi & Article Information \\
Makale Türü - Article Type & Araştırma Makalesi / Research Article \\
Geliş Tarihi - Date Received & 25 Ağustos / August 2021 \\
Kabul Tarihi - Date Accepted & 16 Eylül / September 2021 \\
Yayın Tarihi - Date Published & 20 Eylül / September 2021 \\
Yayın Sezonu & Temmuz - Ağustos - Eylül \\
Pub Date Season & July - August - September
\end{tabular}

Atıf / Cite as: Uçar, A. (2021), Pîr Muhammed Mevlevî’nin Hazînetü’l-Ebrâr İsimli Eserinin 4. Cildinde Bir Ayetin İrşat Şekli/ Guidance Form of a Verse in the 4th Volume of Pir Muhammad Mawlawi's Khazinat al-Abrar. Turkish Academic Research Review, 6 (3), 920-934. Retrieved from https://dergipark.org.tr/tr/pub/tarr/issue/64962/987120

Íntihal / Plagiarism: Bu makale, en az iki hakem tarafından incelenmiş ve intihal içermediği teyit edilmiştir. / This article has been reviewed by at least two referees and confirmed to include no plagiarism. https://dergipark.org.tr/tr/pub/tarr

Copyright (C) Published by Mehmet ŞAHIN Since 2016- Akdeniz University, Faculty of Theology, Antalya, 07058 Turkey. All rights reserved.

Turkish Academic Research Review - Türk Akademik Araştırmalar Dergisi 


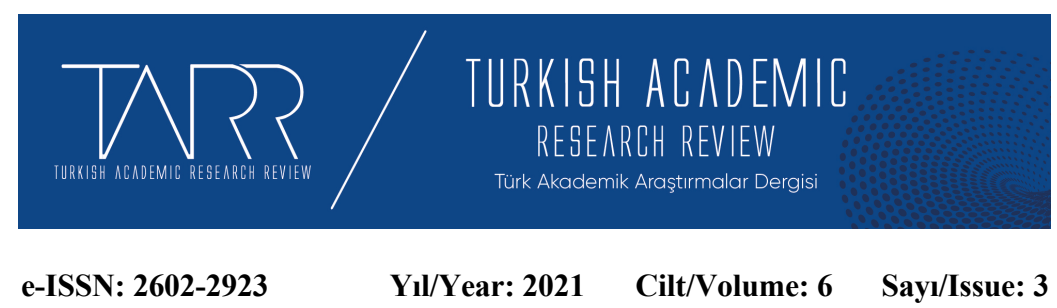

\title{
Pîr Muhammed Mevlevî’nin Hazinetü'l-Ebrâr İsimli Eserinin 4. Cildinde Bir Ayetin İrşat Şekli ${ }^{1}$
}

\author{
Abdullah UÇAR
}

\section{$\ddot{O} \mathbf{z}$}

Mevlânâ'nın yaklaşı 26 bin beyit ve altı defterden meydana gelen Mesnevî-yi Ma'nevî adlı eseri, Türk edebiyatında en çok șerh edilen eserlerden biridir. Geçmişten günümüze Mesnevî-yi Ma'nevî’ye muhtelif hacimlerde pek çok şerh kaleme alınmıştır. Pîr Muhammed Mevlevî de, 17. yüzyılın Mesnevî-yi Ma'nevî şarihlerinden biridir. Klasik eserlerde hayatı hakkında detaylı bilgi bulamadı̆̆ımız Pîr Muhammed Mevlevî'nin kendisinden sonraki Mesnevî şarihlerini etkilediği konusunda hiç şüphe yoktur. Öyle ki Hazînetü'l-Ebrâr'dan sonra yazılan Mesnevî șerhlerinde mahlası olan Cân-1 Âlem ifadesi zikredilmektedir. Pîr Muhammed Mevlevî tarafından kaleme alınan Hazînetü'l-Ebrâr, 17. yüzyıla ait Mesnevî-yi Şerif şerhlerinden biridir. Hazînetü'l-Ebrâr'ın nüshaları ile ilgili kaynaklarda farklı bilgiler mevcuttur. Bazı araştırmacılar Pîr Muhammed'in Mesnevî’nin ilk dört cildini şerh ettiğini ancak ilk iki cildin nüshalarına ulaşılamadığını ve onun Mesnevî'yi Hazînetü'l-Ebrâr adıyla 1026/1617 yılında tamamladığını söylemiştir. Bazı araştırmacılar Hazînetü'l-Ebrâr'ın Mesnevî'nin sadece dördüncü cildinin şerhi olduğunu söylemiştir. Bazı araştırmacılar ise Pîr Muhammed'in 4. cildin şerhini 1617 'de tamamladığını ve aynı yıl vefat ettiğini söylemiştir. Ancak son yapılan akademik çalışmalar Pîr Muhammed Mevlevî’nin, Mesnevî’nin altıncı cildine de șerh yazdığını kanıtlar niteliktedir. Hazînetü'l-Ebrâr'ın 4. cildinin "temme" kısmındaki bilgiye göre eser, hicri 1026 senesinin başında muharrem ayının sonunda tamamlanmıştır. $\mathrm{Bu}$ tarih miladi olarak 1617 senesinin ocak veya şubat ayına tekabül etmektedir. Bu çalıșmada Hazînetü'l-Ebrâr hakkında kısaca bilgi verilmiș, Hazînetü'l-Ebrâr'ın 4. cildinde en çok zikredilen Bakara suresinin 216. ayetinin irşat şekli tespit edilmeye çalışılmıştır. Hazînetü'l-Ebrâr'ın 4. cildinde en çok zikredilen ayet Bakara suresinin 216. ayetidir. Çalışmamızda ayetlerin yerlerini belirtmek için Pertev Paşa nüshasındaki varak numaraları esas alınmıştır. Bakara suresi 216. ayetin nerelerde ve hangi amaçla kullanıldığını belirtmek için ayetler, kullanıldı̆̆ bağlam içinde verilerek değerlendirmeye çalışılmıştır.

Anahtar Kelimeler: Pîr Muhammed, Hazînetü'l-Ebrâr, Mevlânâ, Mesnevî, Bakara $2 / 216$.

$1 \mathrm{Bu}$ makale, yazarın, Niğde Ömer Halisdemir Üniversitesi Sosyal Bilimler Enstitüsünde yapmakta olduğu "Pîr Muhammed Efendi, Hazînetü'l-Ebrâr, IV. Cilt" adlı doktora tezinden üretilmiştir.

Turkish Academic Research Review - Türk Akademik Araştırmalar Dergisi 


\title{
Guidance Form of a Verse in the 4th Volume of Pir Muhammad Mawlawi's Khazinat al-Abrar
}

\begin{abstract}
Rumi's work called Masnavi-ye-Ma'navi, which consists of approximately 26 thousand couplets and six volumes, is one of the most annotated works in Turkish literature. From past to present, many commentaries have been written on Masnaviye-Ma'navi in various volumes. Pir Muhammed Mevlevi is also one of the 17th century Masnavi-ye-Ma'navi commentators. There is no doubt that Pir Muhammed Mevlevi, whose life we cannot find detailed information about in classical works, influenced the Masnavi commentators after him. So much so that in the Masnavi commentaries written after Hazinetü'l-Ebrar, the phrase Can-1 Alem, which is its pseudonym, is mentioned. Hazinetü'l-Ebrar, written by Pir Muhammed Mevlevi, is one of the 17th century Masnavi-ye-Ma'navi annotations. There is different information in the sources about the copies of Hazinetü'l-Ebrar. Some researchers said that Pir Muhammad commented on the first four volumes of the Masnavi, but the copies of the first two volumes could not be reached and he completed the Masnavi in 1026/1617 under the name Hazinetü'l-Ebrar. Some researchers have said that Hazinetü'l-Ebrar is only an annotation of the fourth volume of Masnavi. Some researchers say that Pir Muhammed completed the commentary of the 4th volume in 1617 and died in the same year. However, recent academic studies prove that Pir Muhammed Mevlevi also wrote annotations on the sixth volume of Masnavi. According to the information in the "temme" part of the 4th volume of Hazinetü'lEbrar, the work was completed at the end of Muharram at the beginning of Hijri 1026. This date corresponds to January or February of 1617 Gregorianly. In this study, brief information about Hazinetü'l-Ebrar is given, and the form of guidance in the 216th verse of the Surah Baqara, which is most mentioned in the 4th volume of Hazinetü'l-Ebrar, has been tried to be determined. The most mentioned verse in the 4th volume of Hazinetü'l-Ebrar is the 216th verse of the chapter of Baqara. In our study, the leaf numbers in the Pertev Pasha copy were taken as a basis to indicate the places of the verses. In order to indicate where and for what purpose the 216 th verse of Surah al-Baqara is used, the verses have been tried to be evaluated by giving them in the context in which they are used.
\end{abstract}

Keywords: Pir Muhammad, Hazinetü'l-Ebrar, Rumi, Masnavi of Rumi, Surah alBaqara 2/216.

\section{Structured Abstract}

Since Mesnevî-yi Şerif is a very powerful work in terms of content and narration method, and due to the richness of its Islamic, literary, mystical and philosophical layers, a new interpretation has emerged in every reading and writing, and the translations and commentaries written for Mesnevi have become almost copyrighted works. Since Masnavi is a voluminous work, sometimes it could not be translated or annotated completely. Numerous academic publications have been made around the world about Masnavi, which has been translated or annotated many times since the time it was written.

In this study, Hazinetü'l-Ebrar, which is a Masnavi commentary, is briefly introduced and the determinations about the way of guidance of the 216 th verse of the Surah Baqara, which is most used in the commentary of the 4th volume, have been tried to be presented for the benefit of the researchers. In the study, general information about the work and the paragraphs in which the 216th verse of Bakara Surah is included in the commentary are given, and then the commentary text and

Turkish Academic Research Review - Türk Akademik Araştırmalar Dergisi 
922 Pîr Muhammed Mevlevî’nin Hazînetü’l-Ebrâr İsimli Eserinin 4. Cildinde Bir Ayetin İrşat Şekli

the verse are evaluated. In order to show which Masnavi couplet or title is used in the explanation of the verses, the relevant Persian couplet or title of the Masnavi is also included in the study.

Hazinetü'l-Ebrar is a commentary on Masnavi written in the 17th century. There is no detailed information about the author of the work in the sources. We learn from the last part of Hazinetü'l-Ebrar that Pir Muhammed Mevlevi (aka Cân-1 Alem), the author of the work, was born in Balıkesir and lived in Istanbul. According to the information in the "temme" part of the copy of the work, which was studied as a doctoral thesis by us, the work was completed at the end of Muharram at the beginning of Hijri 1026. This date corresponds to the January or February of 1617 in Gregorian terms. Although it has been stated in the studies that there is an annotation for Hazinetü'l-Ebrar that includes the first four volumes of Masnevi, recent academic studies prove that Pir Muhammed Mevlevi wrote annotations on all six volumes of Masnavi. Researchers talk about four copies that are said to belong to Hazinetü'l-Ebrar. There are different expressions in the sources about the volume of the copies.

The first copy mentioned in the publications is registered at number 33 in the Süleymaniye Library, Halet Efendi. The commentary on Masnavi, registered under the name Şerhü'l-Mesnevi and missing the beginning, belongs to the first volume. The copy begins with the commentary of the 1646th couplet and ends with the last couplet of the first volume. In the copy, most of the first volume of Mesnevî has annotation. Pir Muhammad annotated the couplets verse by verse, not as a whole. Another copy, which is registered to Pir Mehmed Efendi under the name Hazinetü'lEbrar, located in the Süleymaniye Library Halet Efendi Collection number 179, is the Persian commentary belonging to the third volume of Masnavi. There is no record at the beginning and end of the copy about the annotation and the date of writing of the work.

In the catalog scans made by us, 2 copies of Hazinetü'l-Ebrar were identified. Both of these copies belong to the 4th volume of the Masnavi. One of the copies is registered at the Topkap1 Palace Revan Mansion R.440. This copy consists of 318 leaves, there are 33 lines on each page and has been copied with ta'lik line. The other copy is registered at the Suleymaniye Library Pertev Pasha Collection number 308. This copy consists of 529 leaves, there are 31 lines on each page and has been copied with nesih calligraphy.

While explicating Masnavi, Pir Muhammed Mevlevi used verses, hadiths, Arabic and Persian poems belonging to different poets, couplets, verses, polite words, etc. has used.

Pir Muhammed Mevlevi translated the Masnavi couplet before starting the commentary, and then he commented on it. During the commentary, he narrated a story about the subject, if any.

Pir Muhammed Mevlevi sometimes mentioned couplets in different volumes of Masnavi that complement each other in terms of meaning.

The most mentioned verse in the 4th volume of Hazinetü'l-Ebrar is the 216th verse of the chapter of Baqara. In our study, the leaf numbers in the Pertev Pasha copy were taken as a basis to indicate the places of the verses. In order to indicate where and for what purpose the 216th verse of Surat al-Baqara is used, the verses have been tried to be evaluated by giving them in the context in which they are used. 


\section{Giriş}

Mesnevî-yi Şerif, içerik ve hikâye etme usulü bakımlarından çok güçlü bir eser olduğu için İslami, edebî, tasavvufi ve felsefi katmanlarının zenginliği sebebiyle her okuma ve yazmada yeni bir yorum ortaya çıkmış, Mesnevî için yazılan tercüme ve şerhler âdeta telif eser niteliği kazanmıştır.

Mesnevî-yi Şerif, hacimli bir eser olduğu için bazen tamamı tercüme veya şerh edilememiştir. Yazıldığı dönemden itibaren birçok kez tercümesi veya şerhi yapılan Mesnevî hakkında dünya genelinde sayısız akademik yayın yapılmıştır.

Bu çalışmada bir Mesnevî şerhi olan Hazînetü’l-Ebrâr kısaca tanıtılmaya ve 4. cildin şerhinde en çok kullanılan Bakara suresi 216. ayetin irşat şekli hakkındaki tespitler araştırmacıların istifadesine sunulmaya çalışılmıştır. Çalışmada, eser hakkında genel bilgi ve Bakara suresi 216. ayetin şerh içinde geçtiği paragraflar verilmiş, sonrasında da şerh metni ve ayet değerlendirilmiştir. Ayetlerin hangi Mesnevî beytinin veya başlığının izahında kullanıldığını göstermek için Mesnevî’nin ilgili Farsça beyti veya başlığı da çalışmada yer almıştır.

\section{Hazînetü'l-Ebrâr}

Hazînetü'l-Ebrâr, 17. yüzyılda yazılmış bir Mesnevî-yi Şerif şerhidir. Eserin müellifi hakkında kaynaklarda detaylı bilgi yoktur. Eserin müellifi olan Pîr Muhammed Mevlevî'nin (nam-1 diğer Cân-1 Âlem) Balıkesir'de doğduğunu ve İstanbul'da yaşadığını Hazînetü'l-Ebrâr'ın son kısmından öğreniyoruz.

Eserin tarafımızca doktora tezi olarak çalışılan nüshasının "temme" kısmındaki bilgilere göre eser, hicri 1026 senesinin başında muharrem ayının sonunda tamamlanmıştır. Bu tarih miladi olarak 1617 senesinin ocak veya şubat ayına tekabül etmektedir.

Araştırmalarda Hazînetü'l-Ebrâr için Mesnevî'nin ilk dört cildini içeren bir şerh olduğu belirtilmişse de son yapılan akademik çalışmalar Pîr Muhammed Mevlevî'nin Mesnevî’nin altı cildine de şerh yazdığını kanıtlar niteliktedir (Güngör, 2019: 226).

Araştırmacilar Hazînetü'l-Ebrâr'a ait olduğu söylenen dört nüshadan bahsetmektedir. Kaynaklarda nüshaların hangi cilt olduğu konusunda farklı ifadeler yer almıştır (Özdemir, 2016: 477).

Yayınlarda bahsedilen ilk nüsha Süleymaniye Kütüphanesi Halet Efendi 33 numarada kayıtlıdır. Şerhü’l-Mesnevî adıyla kayıtlı ve başı eksik olan Mesnevî şerhi

Turkish Academic Research Review - Türk Akademik Araştırmalar Dergisi https://dergipark.org.tr/tr/pub/tarr 
924 Pîr Muhammed Mevlevî’nin Hazînetü’l-Ebrâr İsimli Eserinin 4. Cildinde Bir Ayetin İrşat Şekli

birinci cilde aittir. Nüsha 1646. beytin şerhi ile başlamakta ve birinci cildin son beytiyle bitmektedir. Nüshada, Mesnevî’nin birinci cildinin büyük bir kısmının şerhi bulunmaktadır. Pîr Muhammed, beyitleri bütün olarak değil mısra mısra şerh etmiştir. Bir diğer nüsha olan Süleymaniye Kütüphanesi Halet Efendi Koleksiyonu 179 numarada bulunan Pîr Mehmed Efendi ismine Hazînetü'l-Ebrâr adıyla kayıtlı olan eser ise Mesnevî’nin üçüncü cildine ait Farsça şerhtir. Eserin şârihi ve yazılış tarihiyle ilgili nüshanın başında ve sonunda herhangi bir kayıt bulunmamaktadır (Özdemir, 2016: 477).

Tarafımızca yapılan katalog taramalarında Hazînetü'l-Ebrâr'a ait 2 nüsha tespit edilmiştir. $\mathrm{Bu}$ nüshaların ikisi de Mesnevî-yi Şerif'in 4. cildine aittir. Nüshalardan biri Topkapı Sarayı Revan Köşkü R.440 numarada kayıtlıdır. Bu nüsha 318 varaktan oluşmaktadır, her sayfada 33 satır vardır ve ta'lik hat ile istinsah edilmiştir. Diğer nüsha ise Süleymaniye Kütüphanesi Pertev Paşa Koleksiyonu 308 numarada kayıtlıdır. Bu nüsha 529 varaktan oluşmaktadır, her sayfada 31 satır vardır ve nesih hat ile istinsah edilmiştir.

Tarafımızca doktora tezi olarak Hazînetü'l-Ebrâr'ın transkripsiyonlu metni hazırlanmış, sonrasında edisyon kritik yapılarak detaylı incelemesi yazılmıştır.

\section{Bakara Suresi 216. Ayetinin İrşat Şekli}

Pîr Muhammed Mevlevî, Mesnevî’yi şerh ederken ayetlerden, hadislerden, farklı şairlere ait Arapça ve Farsça şiirlerden, beyitlerden, mısralardan, kelam-1 kibarlardan vs. istifade etmiştir.

Pîr Muhammed Mevlevî, şerhe başlamadan önce Mesnevî beytini tercüme etmiş, sonrasında da şerhe geçmiştir. Şerh esnasında varsa konuyla ilgili bir hikâye nakletmiştir.

Pîr Muhammed Mevlevî, bazen Mesnevî’nin farklı ciltlerinde geçen anlam bakımından birbirini tamamlayan beyitleri de zikretmiştir.

Hazînetü'l-Ebrâr'ın 4. cildinde en çok zikredilen ayet Bakara suresinin 216. ayetidir. Çalışmamızda ayetlerin yerlerini belirtmek için Pertev Paşa nüshasındaki varak numaraları esas alınmıştır. Bakara suresi 216. ayetin nerelerde ve hangi amaçla kullanıldığını belirtmek için ayetler, kullanıldığı bağlam içinde verilerek değerlendirmeye çalışılmıştır:

\section{Pertev Paşa nüshası 13a'dan nakledilmiştir:}


Tamāmì-yi hikāyet-i ān 'āşık ki ez'ases begirihht derbāg̀ sürh-ı şerif ve bu sersühban-ı lațif ol 'āşıkuñ hikāyesinüñ tamāmıdur ki 'asesden kendünüñ mechūli bir bāg̀a kaçdı ma şūḳarā derbāg் yāft ma şūkayı bāg̀da buldı ü 'asesrā ezşādi du'ā-yı hayr mỉkerd ve şādi vü ferhunde 'asese hayr du'ā eyledi ü güft āyet-i kerimeyi ol maḥalde didi ya'ni bunuñ ma'nāsı tamām derk ü şühūd itdüm didi ya ni Hak Te'ālā Hażreti buyurdı ki bu cihānda her şey ki senüñ nefsüñe mekrūh u nāmülāyim gele ki sen andan nefret ü irāà eylersin ol saña hayrdur bu hod kelime-yi cāmi adur mukarrer 'ases dahı bu cihānuñ mekārihindendür ben anlardan havfumdan firār idüp bilmedügim bir bāg்a düşmişdüm filhakikika baña ol 'ases ḩayr oldı ki nāgehāni ma şūḳamı ol bāg̀da buldum bu āyet-i kerimenüñ mefhūm-ı şerifini vicdāni żevk ü şühūd itdüm didi ve 'asese hayr du'ālar eyledi elhāsıl ma lūm oldı ki emr-i

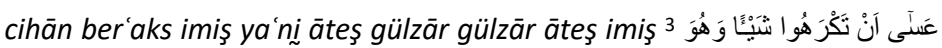

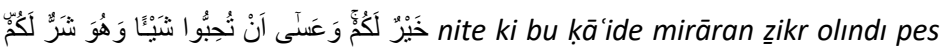
imdi Meŝnevi-yi şerif 'alelhușūș cild-i rābi' ki ahsen-i merābi'dür halk-ı cihānuñ mechūli bir bāg̀-ı nūrānĩdür ki insān-ı kāmilüñ netice-yi dil ü cānıdur cümlesinüñ makșūdı olan maşūḳ-ı mainevi anda mahfi vü nihāndur 'ases ki iblissü̈r eşedd-i mekārihdür nite ki ol cüvān evvel bir kerre ma şūḳasını görüp 'āşık olmış idi lākin maşūḳa berāy-ı imtihāan u belvā-yı istignnā idüp kendüsini pinhān eylemiş idi pes ol 'āşık anuñ derdine düşüp her cānibe yilerken bir gice nāgehāni 'asesden firār idüp bir bāg̀a düşüp anda ma şūḳasına vāṣıl oldı kezāilik țālib ü 'āşık dahı ol mahbūb-ı

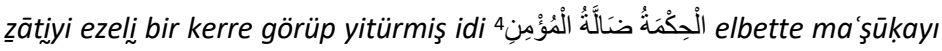
görüp 'āşık olan hod țālib olur pes gerekdür ki teşne șuyı țaleb eyler gibi yāhūd maḥbūbını yitüren 'āşık gibi ol ma'şūḳ-ı maineviye țālib olup her cānibe [P13b] revān ola mādemki z̧ulümāt-ı țabiّat u leyāli beşeriyette ases-i iblisüñ güżergāhından ḳaçup bāg்-ı nūrāni ve gülzār-ı ma'nevĩye ilticā itmeye aña vușūl müyesser olmaz pes gerekdür ki țālib erbāb-ı dilüñ șohbet-i şeriflerine dāhil olup kelām-ı şeriflerinden nūr u żiyāpeżir ola tā ki

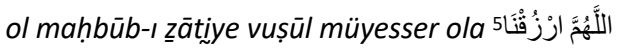

Görüldüğü gibi Bakara suresinin 216. ayetinin bir kısmı ilk olarak Farsça başlık içinde geçmektedir. Şerh kısmında da aynı ayet biraz daha uzun olarak tekrarlanmıştır. Ayetin izahı için "Bu cihanda senin nefsine kötü görünen her şeyden nefret edersin fakat o senin için hayırlıdır" ifadesi kullanılmıştır. Bu başlı̆̆ın şerhinde bir hadis ve bir dua da yer almıştır.

\footnotetext{
2 "Olur ki, bir şey sizin için hayırlı iken, siz onu hoş görmezsiniz." (Bakara 2/216)

3 "Olur ki, bir şey sizin için hayırlı iken, siz onu hoş görmezsiniz. Yine olur ki, bir şey sizin için kötü iken, siz onu seversiniz.” (Bakara 2/216)

${ }^{4}$ Hikmet, müminin yitik malıdır. (Tirmizi, İlim, 19; İbn Mâce, Zühd, 17)

${ }^{5}$ Allah'ım bizi rızıklandır.
} 
926 Pîr Muhammed Mevlevî’nin Hazînetü’l-Ebrâr İsimli Eserinin 4. Cildinde Bir Ayetin İrşat Şekli

2. Pertev Paşa nüshası 19a'dan nakledilmiştir:

Ýn gile z'ān ni meti kun k'et zened

Belki bu şikāyeti ol bir ni metden eyle ki saña țoḳınur ya ni saña irişür

Ezder-i mān dūr u mațrūdet kuned

Bizüm ḳapımuzdan seni dūr u mațūd eyler ya'ni așl şikāyeti bu 'azָim devlet ü ni'met-i 'adāyid gökden eyle ki seni bizüm dergāhımuz[dan] dūr u mațrūd eyler k'et zenedde ki 'illet olup bu ma'nā dahı mümkindür zirrā seni urur bizüm ḳapımuzdan dūr u mațrūd eyler filhakikika şikāyet idicek budur görmez misin ümem-i sālifenüñ țuġyānına sebeb firāvān ni'mete nāyil olduḳları olmışdur ki ziyāde māl u riyāsete mālik olup kemāl-i șı̣hhat ü 'áfiyetde olduḳlariçün Hudā-yı Te'ālā Hażretini ferāmūş idüp azmışlardur lācerem anlara nisbetle devlet ü ni'met ve māl u riyāset kahr-ı hafidür ammā mü'mine ve erbāb-ı 'aşk u mahabbete faḳr u fenā ve derd ü belā

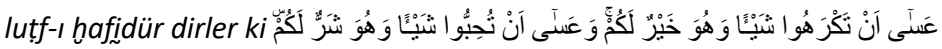
bu kā̄ide hod mirāran żikr olınmışdur Resūl-i Ekrem șallallāhu 'aleyhi vesellem hażretinden mervidür ki buyurmışlar bir kimseyi ki göresiz Hudāyı Te'ālā aña murādını vire hāalbuki ol ma'ṣıyetde kāyim ola biliñüz ki ol devlet ü ġınā aña istidrācdur

$\cdots$

Hikāyet

İbn 'Abbāsdan mervidür ki enbiyā-yı sālifeden biri Hudā-yı Te'ālā Hażretine münācāt eyler ki ey Hudā-yı müte'āl bu 'aceb sırdur ki bir mü'min-i șādık saña cürm ü ma șıyetden ictināb eyler aña faḳr u fenā ve belālar musallaț eylersin kāfir küfr ü ḍalāletinde mușırdur anuñ dünyāsına vüs'at ü mizācına șıhhat virürsin pes Hak Te'ālā Hażretinden aña vahy geldi ki ol mü’min-i șādıkdan gāh olur hațāa șādır olur cezāsını āhirete komayup faḳr u fenā musallaț idüp anı tażyik eylerüm tā keffāret-i żünūb ola ve dergāhımuza pāk u lațif gelüp ni metimüze vāṣıl ola ammā erbāb-ı küfr ü ḍalāletden gāh olur ki bir emr-i müstahsin zāahir olur pes anuñ 'ivażını āhirete komayup 'ivażını ta'cil iderüz aña murād ne māl u șıhhhat virürüz tā ki āhirete habāŝet ü cürmile gelüp cezāsını bula pes erbāb-ı kulūb dünyānuñ mekārihi cānına māyil olduḳlarına sebeb budur

$\mathrm{Bu}$ örnekte Bakara suresi 216. ayetten hemen önce eski ümmetlerin azma sebebinin bolca nimete kavuşmak olduğu belirtilmiştir. Çok mal ve makama sahip olup sağlıklı oldukları için de Allah Teâlâ'yı unutmuşlar, denilmiştir. Müminler için nimetler, makam ve mal sıkıntı iken fakirlik, yokluk ve musibetler lütuftur, ifadeleri kullanılmıştır ve bu ifadelerin sonrasında ilgili ayet-i kerime zikredilmiştir. Devamında da ayetin meali verilerek açıkça ne ifade edilmek istendiği belirtilmiştir. Beytin şerhinde konuyla ilgili bir de hikâye kullanılmıştır. 


\section{Pertev Paşa nüsshası 54a'dan nakledilmiştir:}

\section{Lezzzet-i ū fer'-i mahvv-ı lezzzetest}

Anuñ lezzzeti maḥv-ı lezzzetüñ fer'idür ya'ni cihānda ekl ü şurbuñ ve ġayrı ārzū-yı nefs ü mukteżā-yı țabi'atuñ ki lezzzet ü șafā zan idüp anlarda mütehālik olursın anuñ terk-i mahvi dahı leżiz ü elezdür lākin sen andan

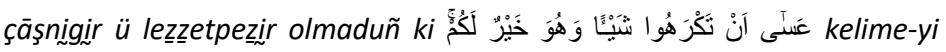
cāmi'a ve kāāide-yi külliyye idügi mirāran żikr ü beyān olınmışdur meŝelā ekl ü şurbuñ tedricle terkinde olan șafā vü lezzzet zāhirdür ki hakiָmāne teenni ile münḳațı olup ġıdā-yı rūḥāniden muġtedi olanlar anuñ terkinde olan çāşnĩden șafāpeżir olmışlardur 'ālem-i dünyā vü mertebe-yi eşbāḥuñ her țavrı böyledür

$\mathrm{Bu}$ beyitte bahse konu olan ayet zikredilmeden önce şu ifadeler kullanılmıştır: "İnsan, yemeyi, içmeyi ve tabiatı gereği nefsinin diğer isteklerine uymayı lezzetli zanneder. Gerçek lezzeti bunlar sanıp kendini bunlar için helak eder. Fakat bunları terk etmek daha lezzetlidir." Ayetteki iyinin kötü, kötünün iyi sanılması zıtlığı burada insanî istekler üzerinden örneklendirilmiştir.

\section{Pertev Paşa nüshası 94b'den nakledilmiştir:}

\section{Kemterin ān ki nümāyed seng zer}

Mün'akis görünenüñ kemterin ü ednāsı oldur ki țaş altun görinür nite ki

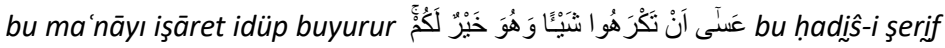

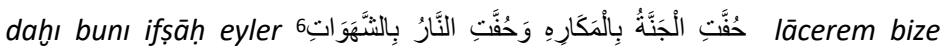
tenbi⿱ idüp Hażret-i Habỉb-i Ekrem șallāhu 'aleyhi vesellem buyurmışdur

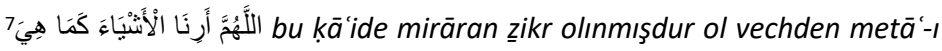
dünyā saña ețāa ü nisvān gibi huūb u lațif görinür

Ayetin burada kullanılması ise Farsça mısrada geçen "taşın altın görünmesi" ile ilgilidir. Ayetten sonra konuya uygun bir de hadis zikredilmiştir. Sonrasında da peygamber efendimizin (sav) “Allah'ım, bize eşyayı olduğu gibi göster.” duası verilmiştir. Bu dua, her şeyin hakikatini yani bir şeyin bizim için iyi mi kötü mü olduğunu bilmenin insan için ne kadar önemli olduğunu göstermektedir.

\section{Pertev Paşa nüshası 116b'den nakledilmiştir:}

\section{Çün ziçeşm-i h̆viş ü halḳān dūr şud}

Çünki ol hażret aḳrabāsınuñ ve halḳınuñ gözinden dūr oldı hy viş hıșm u aḳrabā maināsınadur murād āşinā ve ecnebi cemi halḳdan dūr oldı dimekdür egerçi kendü ma nāsına olmak dahı mümkindür zirāa țālib-i Haḳ olanuñ vücūdı kendünüñ gözinden dahı dūr u mehcūr olur zirā nefsinden

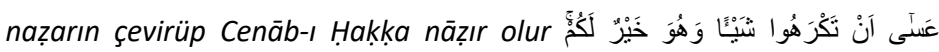

6 "Cennet zorluklarla, cehennem ise aşırı arzularla çevrilmiştir." (Müslim, Cennet, 1, Hadis no: 2822)

${ }^{7}$ Allah'ım, bize eşyayı olduğu gibi göster. (Gazzâlî, İhyâ, I, 642)

Turkish Academic Research Review - Türk Akademik Araştırmalar Dergisi 
928 Pîr Muhammed Mevlevî’nin Hazînetü’l-Ebrâr İsimli Eserinin 4. Cildinde Bir Ayetin İrşat Şekli

mefhūmından șafāpeżir olup nefsine mülāyim olmayan nesnelere māyil olur

Bu misrada ise "temennisi Allah olan kişinin vücudu kendi gözünden bile uzak olur; o, kendi vücudunu dahi görmez çünkü nefsinin isteklerine bakmaz, Allah'a bakar, onun rızasını kazanmayı arzular." ifadelerinden sonra Bakara suresi 216. ayet zikredilerek o kişinin, bu ayetten istifade edip nefsine hoş görünmeyen şeylere meylettiği belirtilmiştir. Buradan, Allah'ın rızasını kazanmak için nefsimize hoş gelmeyen şeylerle iştigal etmemiz gerektiği anlaşılmaktadır.

\section{Pertev Paşa nüshası 155a'dan nakledilmiştir:}

\section{Fạ̣m bāşed mānde ezahger beteft}

Ol teft ü harāretle mevșūf olan āteş ü abgerden fạ̣m-ı siyāh kalmış olur yaini revnak u harāret ve hüsnle görinen dünyā hor u hạkị ḳalur zĩrā anuñ revnak u hüsni 'āriyetdür ki senüñ şehvet ü hırșuñdan mün'akis olmışdur pes 'āḳile ma'ḳūl olan budur ki dünyānuñ hoşnümā olduġına māyil olmayup sırr u maināsına ve 'āḳıbet emrine vāḳı ola ve kemāl-i din ki ehl-i dilüñ kelāmını kabūl idüp h̆ıdmet ü 'ubūdiyyet itmekdür șūret ü z̦āhirde nefsine girān u mekrūh göründügine mukayyed olmayup hakikikat ü

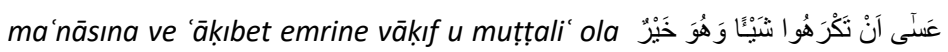

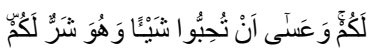

$\mathrm{Bu}$ şerhte ise "gözümüze ve gönlümüze güzel görünen dünyanın değersiz olduğu çünkü onun güzelliğinin geçici olduğu” belirtilmiştir. "Ak1llı insan dünyanın güzelliklerine meyletmez, dünyanın ne olduğunu bilir, bir şeyin suret ve zahirde nefsine kötü görünmesine aldırmayıp onun hakikat ve manasını bilir." ifadeleri kullanıldıktan sonra konuya uygun olan Bakara suresi 216. ayet zikredilmiştir.

\section{Pertev Paşa nüshası 182a'dan nakledilmiştir:}

\section{Z'ān buved ki 'aybeş āmed derẓuhūr}

Andan ötürüdür ki anuñ ḳabāhat ü 'aybı żuhūra geldi ya'ni ol cürm ü günāh ki sen anuñ irtikāb u amelinden nefret ü írāż eyledüñ anuñ vechi oldur ki Hudā-yı Te'ālā Hażreti anuñ kabāḥat ü żararını saña keşf ü 'ayān eyledi yohsa anı dahı perde-yi şehvet ü hevāyla setr ü pinhān ideydi anı ḥıș u mahabbet ile işleyüp niçe kabāhat dahı mürtekib olurduñ ammā ol hușūṣda Hak Te'ālā Hażreti fażl u kereminden seni hıfẓ idüp anuñ żarar u 'aybını gösterdi lācerem andan nefret ü i'rāż eyledüñ meŝelā āteşüñ ị̂āạ u elemini ve necāsetüñ kabāhat ü habāŝetini herkese göstermişdür ol vechden aña yaḳin olmaḳdan nefret ü i'rāż eyler pes zaāhir oldı ki Hak Te'ālā bir ḳulına cürm ü günāhuñ kabāhat ü żararını göstere ol kimse ol günāhdan āteş ü murdārdan kaçar gibi nefret ve firār eyler çün ḳażā bizüm dil ü didemüz liḥikmetin perde-yi hııș u hevāyla setr eyledi pes nik ü bedi kemā yenbagii derk ü şühūda kādir degilüz [P182b] belki bed ü kabịh olan kārı maḳbūl ü maḥbūb z̦an idüp meyl ü mahabbet eylerüz görmez 


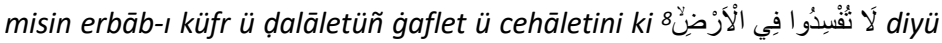

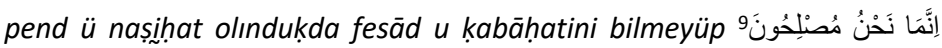
didiler çünki hicāb-ı țabi'at ile mahcūb olan emri ber'aks añladuk pes Hak Tَ'

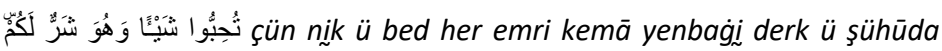
kādir degilsin pes lāzımdur ki dāyim Hudā-yı Te'ālā Hażretine du'ā vü tażarru' idüp ve 'ubūdiyyet ü meskenet iz̧hār eyleyüp cürm ü günāh ve 'acz u noksānımuza mu'terif olavuz ve her dem münācāt idüp bunı ricā eyleyevüz ki tā bizüm perdemüzi keşf idüp her şey’ kemā yenbaği derk ü şühūd müyesser eyleye

Burada ise "Hak Teâlâ, sana ihsan edip seni muhafaza eyledi, eşyanın iyi veya kötü olduğunu sana gösterdi. Böylece sen o şeyden nefret ettin ve uzaklaştın. Mesela Allah Teâlâ, ateşin yakıcılığını, necasetin pisliğini herkese göstermiştir. Bu sebeple insanlar bunlara yaklaşmaz. Yani Allah Teâlâ bir kuluna bir günahın cezasını gösterse o kimse bundan ateşten kaçar gibi kaçar. Allah Teâlâ bizim gözümüzü ve gönlümüzü hırs perdesi ile örtmüştür. Bu sebeple biz iyiyi ve kötüyü idrak etmeye muktedir değiliz. Bu yüzden de kötü olan bir işi iyi zannedip ona meylederiz, onu isteriz. Küfür ehline 'Yeryüzünde fesat çıkarmayın.' diye tavsiye edildiği zaman onlar hatalarının farkında olmadıkları için 'Biz ancak 1slah edicileriz!' diye cevap verdiler.” ifadelerine yer verildikten sonra Bakara suresi 216. ayet zikredilmiş ve sonrasında insanın iyiyi ve kötüyü anlamaya muktedir olmadığı ifade edilmiştir. İnsanın her zaman Allah'a dua ve niyazda bulunması, günahını ve acziyetini itiraf etmesi gerektiği belirtilmiştir. Bu sayede Rabbimiz, gözümüzdeki ve gönlümüzdeki perdeyi kaldıracak ve böylece eşyayı olduğu gibi görmemiz mümkün olacaktır.

\section{Pertev Paşa nüshası 211b’den nakledilmiştir:}

\section{Çün şud ū bĩdār 'aksiyyet nümūd}

Çünki ol kimse hōābdan bĩdār oldı 'aksiyyet görindi yaini insān-ı hayvān

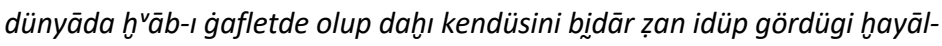
i h̆vāb olduġını bilmeyüp dahı öldükden șoñra zāahir oldug்ı ol kimsenüñ hissi gibidür ki 'ālem-i h̆vābda idi ammā ru'yāsında kendüyi biddār șanup gördügi 'aks ü hayāl idügin bilmezdi çün ol kimse bìdār oldı hiss ü derkinüñ 'aksiyyeti z̦āhir oldı ya'ni hayāli haḳikat ve șūreti ma inā ẓan eyler

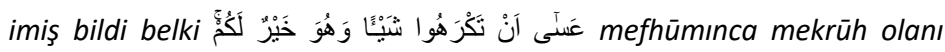
filhakiḳa maḥūb añlar imiş ẓāhir oldı

8 "Yeryüzünde fesat çıkarmayın.” (Bakara 2/11)

9 "Biz ancak 1slah edicileriz!" (Bakara 2/11)

Turkish Academic Research Review - Türk Akademik Araştırmalar Dergisi https://dergipark.org.tr/tr/pub/tarr 
930 Pîr Muhammed Mevlevî’nin Hazînetü’l-Ebrâr İsimli Eserinin 4. Cildinde Bir Ayetin İrşat Şekli

$\mathrm{Bu}$ mısrada ise insanın iyi ile kötüyü birbirinden ayıramaması rüya örneği üzerinden açıklanmıştır: "Bir kimse uykudan uyandı ve gördüklerinin gerçek olmadığını anladı. Yani aslında insan dünyada gaflet uykusundadır fakat kendisini uyanık zanneder. Yaşadıklarının bir rüyaya benzediğini öldükten sonra anlar. İnsan uykudayken kendisini uyanık zanneder yani uykuda olduğunu ve gördüklerinin rüya olduğunu idrak edemez. Uykuda gördüğü rüyayı gerçek sanır.” ifadeleri kullanıldıktan sonra bahse konu ayet zikredilmiş, sonrasında da "kötü olan şeyi sadece mahbup anlar” denilmiştir.

\section{Pertev Paşa nüshası 213b’den nakledilmiștir:}

Çāliş-i 'aḳl bānefs hemçün tenāzu'-ı Mecnūn bānāḳa bu sürh-ı [P213b] şerif 'aḳluñ nefsile ceng ü çāliş̧i Mecnūnuñ nāḳa ile nizā' u mücādelesi gibi olduġınuñ beyānıdur meyl-i Mecnūn sūy-ı hürre vü meyl-i nāḳa vāpes sūy-ı kürre zirā Mecnūnuñ meyli hürre țarafınadur ya ni Leylā cānibinedür ve nāḳanuñ meyli ardına kürre țarafınadur ya'ni küçügi cānibinedür nāḳa devenüñ dişisine dirler kürre țaydur lākin murād bunda devenüñ küçügidür elhāọsıl Mecnūn ki Leylāya 'āşık idi niçe zamān görmemiş idi Leylā gelüyorur diyü istimā' eyledi filhāl nāḳaya binüp ḳarşu gitdi kürresi āhūrda kalmış idi nākanuñ meyli aña olduġıçün ardına çekinürdi lācerem ikisinüñ mābeyninde tenāzu' u keşākeş oldı çünān ki Mecnūn güft ancılayın ki Mecnūn didi

Beyt

Hevā nāḳati halfị ve ḳuddāmiye'l-hevā

Benüm nāḳamuñ mahabbet ü hevāsı benüm ardımadur yaini girüde ḳalan küçügine māyildür ister ki dönüp girü gide hālbuki benüm hevā-yı mahabbetüm öñümdedür ya ni ma şūḳa ve Leylā cānibinedür isterüm ki aña vāṣıl olam

Ve inni ve iyyāhā lemuhtelifāni

Tahḳik ben ve nāḳa muhteliflerüz yaini ikimüzüñ hāli biribirimüze

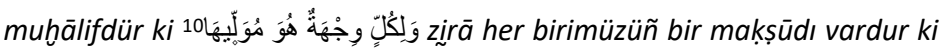
ol aña müvelli vü müteveccihdür vichetun cihet ma'nāsınadur yaini edyānI muhtelife erbābından her birinüñ bir ciheti vardur kııble gibi ol āgāh meyl ü teveccüh idicidür kezāalik nāḳa ile benüm makșūdum muhtelifdür zirāā benüm murādum öñümde ma'şūḳadur nāḳanuñ ardında küçügidür lācerem mābeynimüzde nizā' olup her birimüz țaraf-ı hilāfa çekerüz Mecnuñdan murād bunda rūḥ-ı insāni ve 'aḳl-ı Rabbānidür maḥbūb-ı zāāi ve ma'şūḳ-ı mainevinnüñ 'aşkından divānedür lācerem öñimüzde anuñ żevk-i vușūlini ārzūy u țaleb eyler nāḳadan murād nefs-i hayvānidür ki makșūdı ardımuzda şehvet ü hevādur dāyim aña meyl ü teveccüh eyler ol

10 “Herkesin yöneldiği bir yön vardır.” (Bakara 2/148) 
vechden ikisinüñ mābeyninde nizā' u keşākeş olmışdur çün Mecnūn gördi ki nāḳanuñ hevāsı kendüsine uymaz dāyim murādınuñ hilāfına çekmek

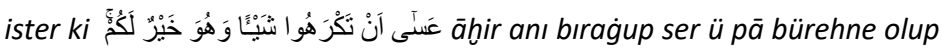
tenhā kendü sür'at eyledi kez̄ālik sen dahı bilkülliyye nefsüñi mukteżāsıyla terk itmeyince ol mahbūb-ı lāyezāle vușūl müyesser olmaz

$\mathrm{Bu}$ örnekte ayet-i kerime yine bir başlığın şerhinde verilmiştir. Başlıktan ayete kadar olan kısım bir bütün olduğu için şerhin tamamı buraya alınmıştır. Başlıkta kullanılan mazmunlar şerhte izah edilmiştir. 'Mecnun'dan murat ruh ve akıldır, 'naka'dan murat nefistir, 'kürre'den murat ise şehvet ve heveslerdir. Bu sebeple nefis, insanı daima kendi heva ve heveslerine çekmeye çalışır. Ruh ve akıl ise diğer tarafa çekmeye çalışır. Sonuçta ikisinin arasında bir mücadele vardır. İnsan, nefsinin isteklerini tamamen terk etmeyince o ebedî ve manevî sevgiliye, Rabbine kavuşamaz. Bu mısrada ise ayetteki zıtlık, Mecnun ve nâkanın isteklerindeki zıtlık ile ilişkilendirilerek verilmiştir. Zira Mecnun'un ve nâkanın istekleri birbirine muhaliftir, Mecnun Leyla'sına kavuşmak isterken nâka yavrusuna dönmek istemektedir.

\section{Pertev Paşa nüshası 330b'den nakledilmiştir:}

\section{Ẓāhiren kār-ı tu vĩrān mĩkunem}

Egerçi z̦āhiren senüñ kāruñı vĩrān eylerüm

\section{Lỉk hāāiriā gülistān mikunem}

Lik maināda bir ḩārı gülistān eylerüm yaini şimdiki hāaüñüñ netĩce vü ŝemeresi hāristāndur pes anı bịhinden ihrāc idüp yirini gülzār-ı mainevi

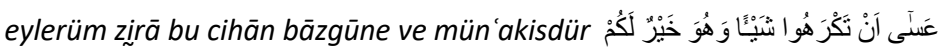
mefhūmınca devlet ü sa'ādet nefsüñ mekārihindedür lācerem bu cihānda vücūd u ġınā faḳr u fenādadur ve dürüsti ve imāret vĩrānı ve harābındadur nite ki bu maḥalden z̦āhir olur

Burada da ayetteki zıtlığın şerhe yansıması vardır. "Ben zahirde senin işini harap ediyor görünsem de aslında bir dikeni gül bahçesi yapıyorum” ifadesi bunu göstermektedir. Devamında da insanın saadetinin nefsin dertlerinde olduğu ifade edilmiştir. Yani bu cihanda varlık ve zenginlik, yok olmak ve fakirliktedir; onu imar etmek için onu yıkmak gerek, denilmiştir.

\section{Pertev Pașa nüshası 345b'den nakledilmiștir:}

Ger hevārā bend binhāde şeved

Eger hevāya bend ḳonmış olaydı

Șayḳalirā dest bügşāde şeved 
932 Pîr Muhammed Mevlevî’nin Hazînetü’l-Ebrâr İsimli Eserinin 4. Cildinde Bir Ayetin İrşat Şekli

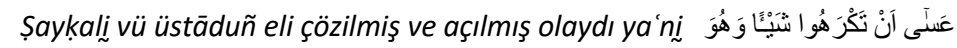
خَبْرٌ لَكُْْ mefhūmınca emri ber'aks itmiş olayduñ

Bu beyitte de ayet, zıtlık sebebiyle kullanılmıştır.

\section{Pertev Paşa nüshası 405b'den nakledilmiştir:}

\section{Z'ān ki dāned k'in cihān-ı kāşten}

Zirrā ki bilür ki bu zirā'at ü kāşten cihānı

\section{Hest behr-i mahşer ü berdāşten}

Rūz-ı haşrdan ötüridür ve anda mahșūl ḳaldurmaḳdan ötüridür yaini

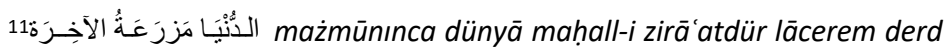
ü belā zamānıdır pes her kim ki āhir ü 'āḳıbetine vāḳıf ola ol zirā'at a'māl içün derd ü belā çekmege 'āşı u māyil olur tā ki rūz-ı haşrda netāyic ü āŝārı hạșṣl ola nite ki emr-i dünyā ber'aks olup āteşi gülzār ve gülzārı nār

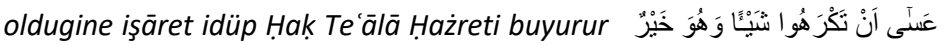

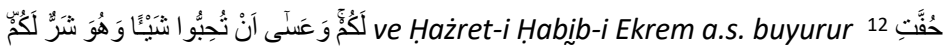

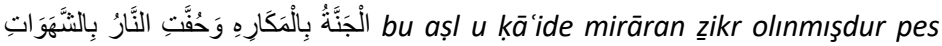
‘āḳıbetbin olan 'ārif derd ü belāda luțf u kerem maḥ̂̃ vü münderic oldugin bilüp cihānuñ zehr ü kahrına māyil olur görmez misin 'ālemde cemi' sūd u menfa'at zaḥmet ü meşaḳkat żımnında mündericdür

Bu beytin şerhinde de dünyanın zıtlığg vurgulanıp ateşin gül bahçesi, gül bahçesinin ise ateş olduğuna işaret edildikten sonra Bakara suresinin 216. ayeti zikredilmiştir. Geleceği gören arif kişi, dert ve belada lütuf ve kerem gizlendiğini bilir ve dünyanın kahrına meyleder. Görmez misin, âlemde bütün fayda ve menfaat, zahmet ve meşakkat içindedir, denilmektedir. Beytin şerhinde iki hadis-i şerif de kullanılmıştır.

\section{Pertev Paşa nüshası 437b'den nakledilmiştir:}

\section{Cehd kun derbihhodi hodrā biyāb}

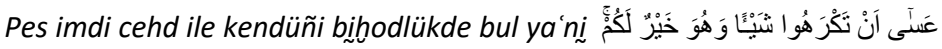
mü'eddāsınca cehd ü himmet idüp kendü hayāt u vücūduñı mevt ü fenāda bul elhạșsıl tebdilli ablāk u țabi at sa'y u himmet eyle

Daha önceki beyitlerde olduğu gibi bu beytin şerhinde de ayetteki zıtlığa vurgu vardır. İnsanın hayat ve vücut bulması yokluğa ve ölüme bağlanmıştır.

\section{Pertev Paşa nüshası 438b'den nakledilmiştir:}

\section{Șūreteş nūrest ü dertaḥ̣kiḳ-i nār}

${ }^{11}$ Dünya, ahiretin tarlasıdır.

12 "Cennet zorluklarla, cehennem ise aşırı arzularla çevrilmiştir." (Müslim, Cennet 1, Hadis no: 2822) 
Anuñ șūreti nūrdur ḥālbuki ḥakikikatde nārdur zirā ol 'ilm ü ma'rifet ki celb-i māl ve kesb-i dünyāya ālet ola șūret ü zāahirde nūr gibi görinür velākin ma'nāda nārdur muțlaḳā devlet böyledür nite ki Hażret-i Habỉb-i Ekrem

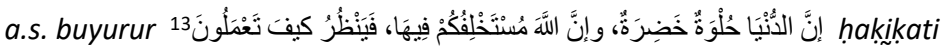

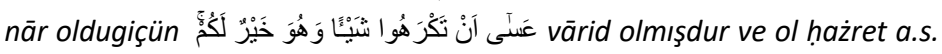
dahı اصحاب الدنيا كما تصحب النار buyurmışdur

"Görünürde nurdur fakat gerçekte ateştir" ifadesiyle bahse konu ayet-i kerime yine zıtlı̆̆ 1 ifade etmek için kullanılmıştır.

\section{Pertev Paşa nüshası 495a'dan nakledilmiştir:}

\section{Har çü bār endāht iskinze zened}

Nite ki ḩar çünki yükini atdı sikize urur ya'ni çifte atup depme urur iskize bunda iskiziden ma'nāsınadur ki depinmek ve bükülmek ma'nāsınadur lākin bunda depme murāddur gāhi hemzeyi iskāạt iderler yaini nefs-i hayvāni maḥv-ı țabia atdur nite ki har yükleyorur yüki arkasından inicek depme urmaġa başlar kez̄ālik ol fāsid ü serkeş dahı ancılayındur yaini derd ü belādan halāṣ olup bār-ı mihnnet üzerinden gidicek ol zārı ve tażarru' ı unudup girü țaği olur pes gerekdür ki dāyim anı keşākeşden huāli āsūde komayup bār-ı girān altında istihdām olına tā ki saña rām olup 'acz u 'ubūdiyyet iẓhār eyleye nite ki mervidür Hak Te'ālā Hażreti nefs-i emmāreyi cehennemde niçe yıllar iḥrāk eyledi hergiz 'aczine mu'terif olmayup "ene" didügin terk itmedi çünki bir sā'at aç koyup muḳteżāsını virmedi feryād u zārị idüp 'acz u 'ubūdiyyetine iḳrār u i'tirāf idüp serfürū

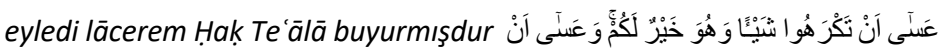
nite ki bu mażmūn mirāran zِikr olındı elhāṣ̂ll nefs-i z̧ālimenüñ țabi'atı cehl ü nisyān üzredür her çend ki başına belā gelür żarūri mużțar olup ehl-i dile mürāca'at eyler ve nāle vü feryād iderek gelüp hāk-i pāyine serfürū eyler çün belā ref' olup āsūde hạal ola ol zārı ve tażarru' I ferāmūş idüp girü țāği vü bāği olur

Bu beytin şerhinde ayet zikredilmeden evvel şu ifadeler yer almıştır: "Hak Teâlâ nefs-i emmāreyi ${ }^{15}$ cehennemde yıllarca yaktı, nefis asla aciz olduğunu itiraf etmeyip 'ben' demeyi bırakmadı. Fakat Hak Teâlâ nefsi bir saat aç bırakınca nefis feryat ve figan edip aciz olduğunu kabul ve itiraf edip Hak Teâlâ'ya itaat etti.” Bu ifadelerden sonra ise şerhin başındaki 'fasit' hikâyesinde olduğu gibi nefsin durumu izah edilmiştir: "Nefsin tabiatı cehalet ve unutma üzerinedir. Her ne zaman başına bir bela gelse feryat ve figan ederek ehl-i dile başvurur, ona itaat eyler fakat

13 "Dünya tatlı, göz kamaştırıcı ve çekicidir. Allah onu sizin kullanmanıza verecek ve nasıl davranacağınıza bakacaktır.” (Müslim, Zikir, 99)

${ }^{14}$ Ateşten kaçar gibi dünyadan kaç.

15 Tasavvufta nefsin yedi mertebesinin insana kötülükleri, günahı ve şehveti emreden ilk mertebesi

Turkish Academic Research Review - Türk Akademik Araştırmalar Dergisi 
934 Pîr Muhammed Mevlevî’nin Hazînetü’l-Ebrâr İsimli Eserinin 4. Cildinde Bir Ayetin İrşat Şekli

başındaki bela ondan uzaklaşıp rahata erince de o inleme ve yalvarmaları unutup tekrar isyana başlar.

\section{Sonuç}

Mesnevî-yi Şerif sadece Mevlevilerin değil tüm dünyanın rağbet ettiği tarikatlar üstü meşhur bir kaynak eserdir. Farklı dinî mezheplerden olan âlimler bile Mesnevî-yi Şerif ile ilgili eser kaleme almışlar ve talebelerinin Mesnevî’yi okumalarını ve ondan istifade etmelerini telkin etmişlerdir.

Bir Mesvevî şerhi olması hasebiyle Hazînetü’l-Ebrâr hacimli ve zengin içerikli bir eserdir. Pîr Muhammed, bir Mesnevî şerhinde kullanılabilecek eserlerin çoğunu kaynak olarak kullanmıştır. Özellikle ayetlerden ve hadislerden istifade etmiştir. Bu çalışmada sadece en çok iktibas yaptığı Bakara suresinin 216. ayeti ele alınmaya çalışılmıştır.

Bakara suresinin 216. ayetinin kullanıldığı misra şerhleri incelendiğinde şerhte zıtlıkla alakalı bir durum söz konusu ise bu ayetin zikredildiği görülmüştür. Bazı mısralarda duyguların zıtlığı, bazılarında durumların zıtlığı, bazılarında ise mazmunların zıtlığı belirtilmek için bu ayetten istifade edilmiştir.

\section{Kaynakça}

Avşar, Z. (2008). Tenkitli Metin Neşrinde İmla Sorunu Üzerine Yeni Düşünce ve Öneriler. Turkish Studies, 3/6, s. 59-95. doi.org/10.7827/TurkishStudies.452

Bursalı M.T. (1333). Osmanlı Müellifleri. İstanbul: Matbaa-i Âmire

Demirel, Ş. (2007). Mevlânâ'nın Mesnevî’si ve Şerhleri. Türkiye Araştırmaları Literatür Dergisi, 5/10 (2007), 469-504.

http://ktp.isam.org.tr/pdfdrg/D02512/2007_10/2007_10_DEMIRELS.pdf

Gölpınarl1, A. (1985). Mesnevi Tercemesi ve Şerhi. İstanbul: İnkılap Kitabevi.

Güleç, İ. (2008). Türk Edebiyatında Mesnevi Tercüme ve Şerhleri. İstanbul: Pan Yayıncilik.

Güngör, Ö. (2019) İsmâil Rüsûhî-yi Ankaravî, Şerh-i Mesnevî, (VI. Cilt), (Doktora tezi) Erişim adresi tez.yok.gov.tr

Özdemir, M. (2016). Mesnevî’nin Türkçe Şerhleri. Turkish Studies, 11/20, 461-502. doi.org/10.7827/TurkishStudies.10093

Pîr Muhammed Mevlevî. Hazînetü'l-Ebrâr, Topkapı Sarayı, Revan Köşkü, nr. R440.

Pîr Muhammed Mevlevî. Hazînetü'l-Ebrâr, Süleymaniye Kütüphanesi, Pertev Paşa, nr. 308.

https://kuran.diyanet.gov.tr/mushaf 